\title{
Endoscopic third ventriculostomy in previously shunted children: a retrospective study. Reply to Professor Viroj Wiwanitkit, M.D. Wiwanitkit House, Bangkhae, Bangkok, Thailand
}

\author{
Elisabetta Marton • Alberto Feletti • Luca Basaldella • \\ Pierluigi Longatti
}

Received: 27 April 2010 /Accepted: 30 April 2010 /Published online: 15 May 2010

(C) Springer-Verlag 2010

\section{Dear Editor}

Our manuscript is an observational retrospective study on a small series of children with shunt malfunction. As stated in the article, we are aware of the limitations of the study, and not least of the fact that no statistically significant conclusions can be drawn. In our experience, endoscopic third ventriculostomy (ETV) secondary to shunt malfunction in pediatric patients had a success rate of $63.64 \%$ in the first month after the procedure. There are only few reports regarding ETV in previously shunted children. Cinalli et al. [3] reported a series of 30 children with third ventriculostomy after shunt malfunction, 23 out of them with endoscopic technique. He reported a success rate of $76 \%$. Other series reported success rates of $71 \%-75 \%[5], 82 \%,[1]$ and $52 \%$ [2] in secondary ETVs in mixed populations of adults and children.

With regard to timing and safety of the procedure, in our experience ETV is a rapid and safe surgery even in emergency condition. It requires training and skills, but once gained, the greater cost effectiveness compared to shunt revision is unquestionable, as it avoids the shuntassociated risks of malfunction and infection $[4,6]$.

\section{References}

1. Boschert J, Hellwig D, Krauss JK (2003) Endoscopic third ventriculostomy for shunt dysfunction in occlusive hydrocephalus: long term follow up and review. J Neurosurg 98:1032-1039

2. Buxton N, Macarthur D, Robertson I, Punt J (2003) Neuroendoscopic third ventriculostomy for failed shunts. Surg Neurol 60:201-204

3. Cinalli G, Salazar C, Mallucci C, Yada JZ, Zerah M, Sainte-Rose C (1998) The role of endoscopic third ventriculostomy in the management of shunt malfunction. Neurosurgery 43:1323-1327

4. de Ribaupierre S, Rilliet B, Vernet O, Regli L, Villemure JG (2007) Third ventriculostomy vs ventriculoperitoneal shunt in pediatric obstructive hydrocephalus: results from a Swiss series and literature review. Childs Nerv Syst 23:527-533

5. O'Brien DF, Javadpour M, Collins DR, Spennato P, Mallucci CL (2002) Endoscopic third ventriculostomy: an outcome analysis of primary cases and procedures performed after ventriculoperitoneal shunt malfunction. J Neurosurg 103:393-400

6. Sainte-Rose C, Piatt JH, Renier D, Pierre-Kahn A, Hirsch JF, Hoffman HJ, Humphreys RP, Hendrick EB (1991-1992) Mechanical complications in shunts. Pediatr Neurosurg 17:2-9 